\title{
The genus Microniphargus (Crustacea, Amphipoda): evidence for three lineages distributed across northwestern Europe and transfer from Niphargidae to Pseudoniphargidae
}

\author{
Dieter Weber ${ }^{1, *}$, Fabio Stoch ${ }^{1}$, Lee R.F.D. Knight ${ }^{2}$, Claire Chauveau ${ }^{1} \&$ \\ Jean-François Flot ${ }^{1,3, *}$ \\ ${ }^{1}$ Evolutionary Biology \& Ecology, C.P. 160/12, Université libre de Bruxelles, \\ Avenue F.D. Roosevelt 50, B-1050 Brussels, Belgium. \\ ${ }^{2}$ No.1, The Linhay, North Kenwood Farm, Oxton, Nr Kenton, Devon, EX6 8EX, United Kingdom. \\ ${ }^{3}$ Interuniversity Institute of Bioinformatics in Brussels - (IB) ${ }^{2}$, Brussels, Belgium. \\ *Corresponding authors: dieter.weber@ulb.be, jean-francois.flot@ulb.be
}

\begin{abstract}
Microniphargus leruthi Schellenberg, 1934 (Amphipoda: Niphargidae) was first described based on samples collected in Belgium and placed in a monotypic genus within the family Niphargidae. However, some details of its morphology as well as recent phylogenetic studies suggest that Microniphargus may be more closely related to Pseudoniphargus (Amphipoda: Pseudoniphargidae) than to Niphargus. Moreover, M. leruthi ranges over 1,469 km from Ireland to Germany, which is striking since only a few niphargids have confirmed ranges in excess of $200 \mathrm{~km}$. To find out the phylogenetic position of $M$. leruthi and check whether it may be a complex of cryptic species, we collected material from Ireland, England and Belgium then sequenced fragments of the mitochondrial cytochrome $c$ oxidase subunit 1 gene as well as of the nuclear 28S ribosomal gene. Phylogenetic analyses of both markers confirm that Microniphargus is closer to Pseudoniphargus than to Niphargus, leading us to reallocate Microniphargus to Pseudoniphargidae. We also identify three congruent mito-nuclear lineages present respectively in Ireland, in both Belgium and England, and in England only (with the latter found in sympatry at one location), suggesting that $M$. leruth $i$ is a complex of at least three species with a putative centre of origin in England.
\end{abstract}

Keywords. Species delimitation, haploweb, K/ $\theta$, DNA barcoding, cryptic species, Microniphargus leruthi.

Weber D., Stoch F., Knight L.R.F.D., Chauveau C. \& Flot J.-F. (2021). The genus Microniphargus (Crustacea, Amphipoda): evidence for three lineages distributed across northwestern Europe and transfer from Niphargidae to Pseudoniphargidae. Belgian Journal of Zoology 151: 169-191. https://doi.org/10.26496/bjz.2021.92

\section{Introduction}

Microniphargus leruthi Schellenberg, 1934 (family Niphargidae) was first described from Engihoul Cave in Wallonia (Belgium) and placed into a new, monotypic genus considered as closely related 
to the genus Niphargus Schiödte, 1849 described 85 years before (SCHIÖDTE 1849; SCHELLENBERG 1934). Microniphargus leruthi is characterised by its small body size (1.2-1.5 $\mathrm{mm}$ in length), the scant setulation of its mandibular palps, an evident protrusion on the carpus of its gnathopods (particularly pronounced on the first pair of gnathopods: KNIGHT \& GLEDHILL 2010) and its telson widely incised with an angle of around $80^{\circ}$ in its indentation, all of which were used to justify the erection of a new genus (SCHELLENBERG 1934). However, several other genera similarly erected on the basis of distinctive morphological features of unknown variability have been synonymized with Niphargus in light of molecular data (see BORKO et al. 2019).

Although $M$. leruthi is presently placed in the family Niphargidae, the shape of its telson is quite similar to that of the genus Pseudoniphargus Chevreux, 1901, which is placed in a different family (Pseudoniphargidae) together with the monotypic Parapseudoniphargus Notenboom, 1988. The taxonomic position of the family Pseudoniphargidae, defined on vague morphological characters, has long been controversial, having been included in the superfamilies Hadzioidea, Niphargoidea, Crangonyctoidea, Gammaroidea or included in the families Gammaridae and Melitidae (see NOTENBOOM 1988 for a detailed analysis). NOTENBOOM (1988) in his cladistic analysis placed the family within the families Eriopisidae and Melitidae, whereas Allocrangonyctidae (comprising two stygobitic species from North America) were later considered as the most closely related family. In fact, in their recent revisions of amphipod taxonomy, LOWRY \& MYERS $(2013,2017)$ included the family Pseudoniphargidae within the superfamily Allocrangonyctoidea, while Niphargidae were allocated to Crangonyctoidea. Recent molecular studies have rejected this hypothesis, suggesting that Pseudoniphargidae are the sister group of Niphargidae (JURADO-RIVERA et al. 2017; MOŠKRIČ \& VEROVNIK 2019; COPILAŞ-CIOCIANU et al. 2020). Although numerous mitochondrial sequences of Pseudoniphargus are available, there are only three partial 28S sequences for this genus and no genetic data at all for the family Allocrangonyctidae and for the genus Parapseudoniphargus, hindering a definitive taxonomic assessment of this clade.

Existing molecular data regarding $M$. leruthi are also scarce, with only 10 sequences available in GenBank so far (FIŠER et al. 2017; MOŠKRIČ \& VEROVNIK 2019), all of which from nuclear markers. No mitochondrial sequence for specimens of Microniphargus has been published so far. MošKRIČ \& VEROVNIK (2019) recovered a (Microniphargus + Pseudoniphargus) clade as a sister group to Niphargus using one protein-coding nuclear gene; however, another protein-coding nuclear marker in the same study yielded a discordant position of Microniphargus within Niphargus. More recently COPILAŞ-CIOCIANU et al. (2020), in a large-scale phylogeny of amphipods based on fragments of the mitochondrial cytochrome $c$ oxidase subunit I and of the nuclear histone 3 (H3), 18S and 28S genes, one Microniphargus, two Pseudoniphargus and two Niphargus species, also recovered Microniphargus as more closely related to Pseudoniphargus than to Niphargus.

Pseudoniphargus comprises 71 stygobitic species (STOKKAN et al. 2018), all strict endemics present in North Africa and Benin, the Mediterranean region, the Iberian Peninsula, the archipelagos of Canaries, Madeira and Azores, and two species in Bermuda, whereas Parapseudoniphargus comprises a single, stygobitic species from southern Spain. By contrast, Microniphargus leruthi is found in north-western Europe: Belgium (LeRUTH 1939; SPANGENBERG 1973; KARAMAN \& RUFFO 1986; DelheZ et al. 1999), Germany (SPANGenberg 1973; KARAMAN \& RUfFo 1986; FuChS 2007; MATZKE et al. 2009; SteIN et al. 2012), Luxembourg (HOFFMANN 1963) as well as Ireland (ARNSCHEIDT et al. 2008; KNIGHT \& PenK 2010; KNight \& Gledhill 2010) and Great Britain (KNiGHT \& GledHILl 2010). The very large range of $M$. leruthi (over $1,469 \mathrm{~km}$ ) is unusual as only a few niphargids have ranges exceeding $200 \mathrm{~km}$ (TRONTELJ et al. 2009): some species previously considered to be wide-ranging, such as Niphargus aquilex Schiödte, 1855 and Niphargus virei Chevreux, 1896, have been found to be complexes of cryptic species (LEFÉBURE et al. 2006; MCINERNEY et al. 2014). The only species with confirmed ranges more extended than M. leruthi are Niphargus hrabei S. Karaman, $1932(>1,300 \mathrm{~km})$ and Niphargus 
valachicus Dobreanu \& Manolache, 1933 (> 3,200 km), two epigean species with enhanced dispersal via surface water (COPILAŞ-CIOCIANU et al. 2017). The wide range of M. leruthi could therefore be due to the presence of undetected species boundaries.

To resolve these uncertainties, we conducted a molecular study on M. leruthi collected in Ireland, England and Belgium using both 28S (nuclear) and COI (mitochondrial) markers. Our aims were (i) to confirm the phylogenetic position of Microniphargus relative to the genera Niphargus and Pseudoniphargus and (ii) to test for the possible existence of cryptic lineages within M. leruthi.

\section{Material and methods}

\section{Sampling and sequencing}

Although we carried out intensive and targeted sampling for M. leruthi, especially in caves around the type locality, we were only able to collect it at a single location on the European continent: the Grotte de Comblain (Wallonia, Belgium), which is $20 \mathrm{~km}$ away from the type locality. We also collected M. leruthi from one site in Ireland (Polldubh, Clare) and two sites in England (Sweetwater Pot, South Devon and Swildon's Hole, Somerset; Fig. 1). All the material (Table 1) was determined morphologically by one of us (L.K.). Specimens were collected by sweeping a long-handle net fitted with a $250 \mu \mathrm{m}$ mesh collecting bag along the bottom and sides of cave pools, making sure to disturb the substrate to suspend both

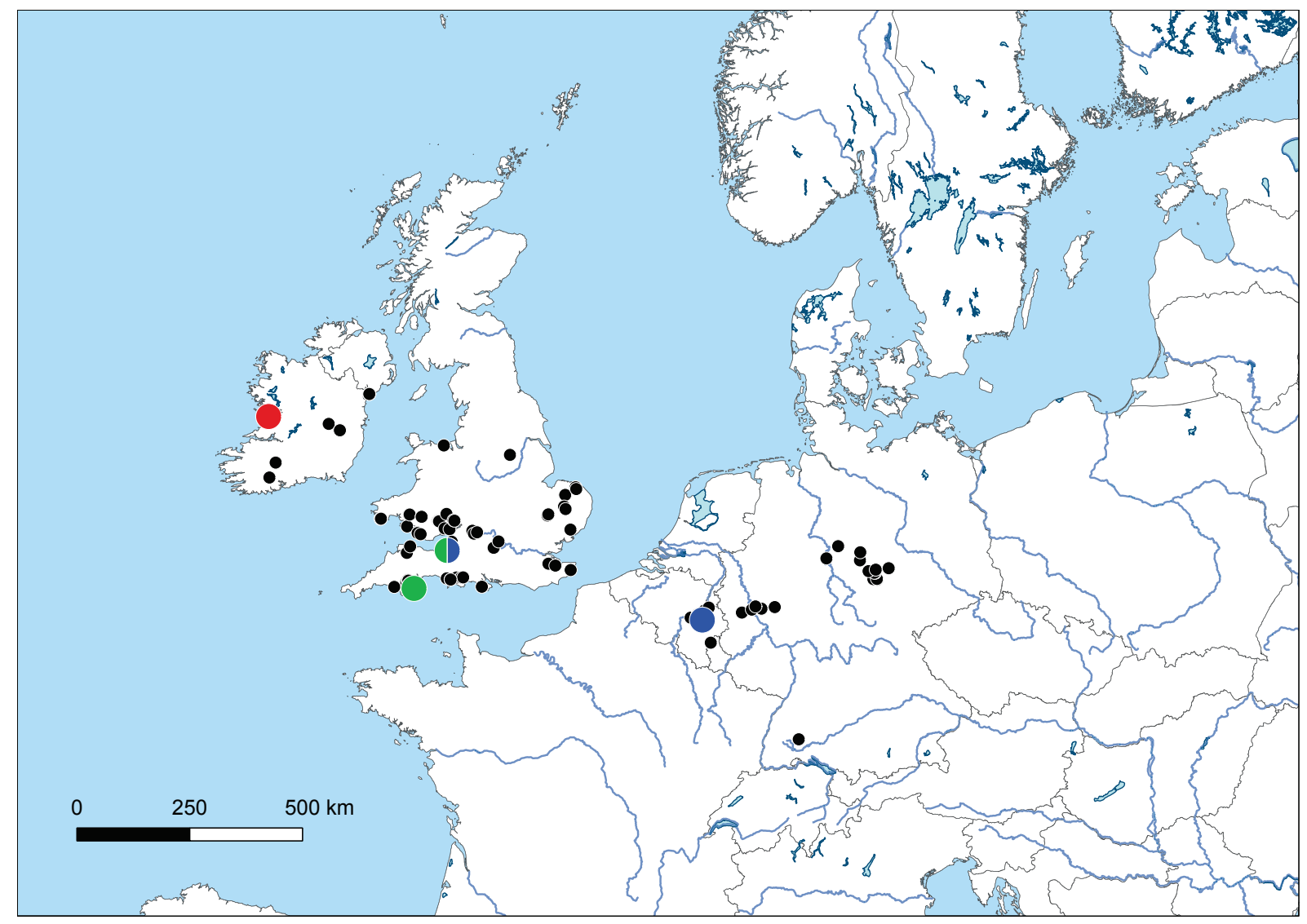

Figure 1 - Map showing the distribution of Microniphargus leruthi. Black dots: literature data based on morphological determination (including https://hcrs.brc.ac.uk/hcrs-database, accessed $27^{\text {th }}$ May 2020). Orange: lineage A; blue: lineage B; yellow: lineage C. 


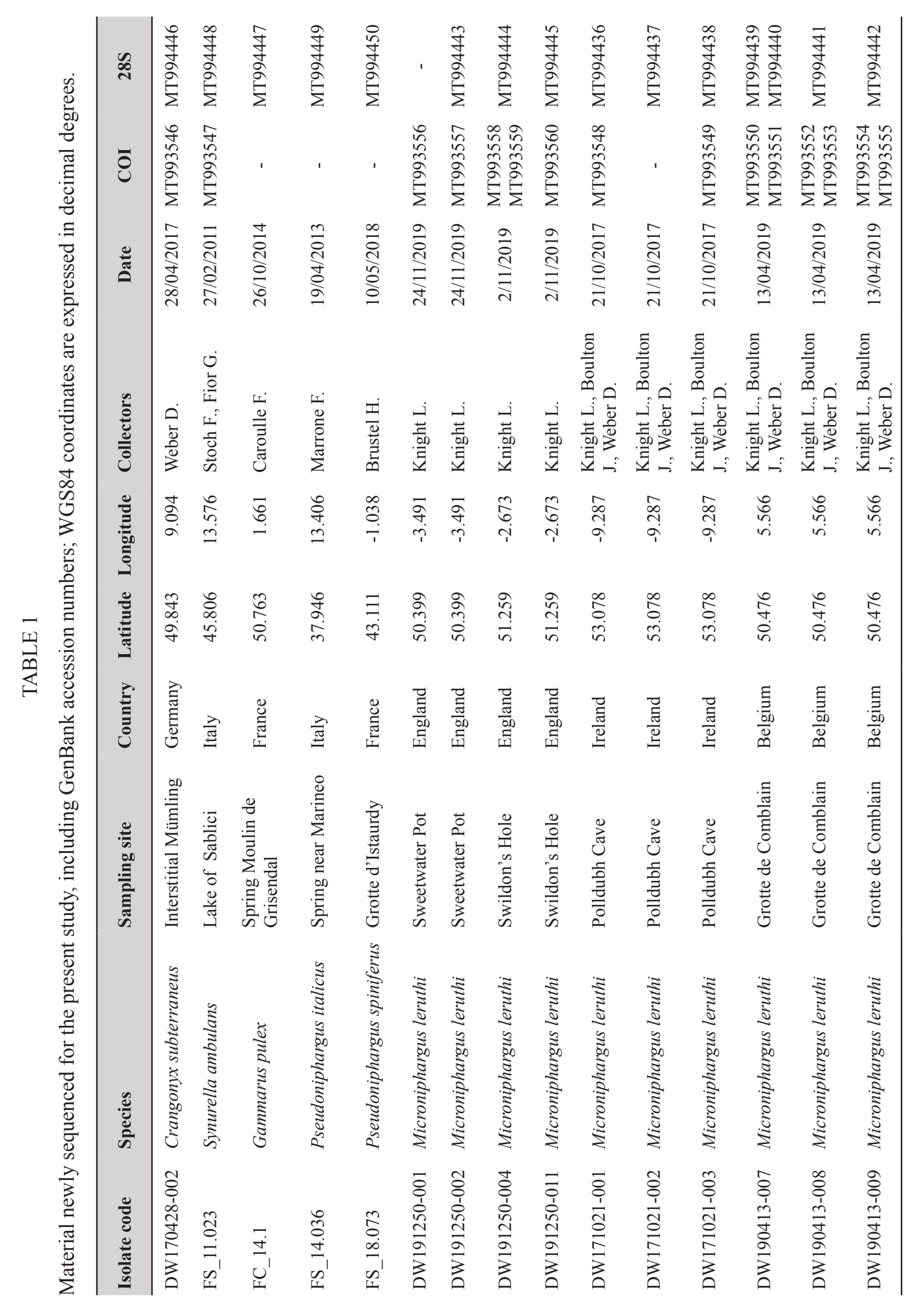


TABLE 2

Primers used in the present study.

\begin{tabular}{|c|c|c|c|c|c|}
\hline Primer & Bases & Marker & PCR & Sequencing & Reference \\
\hline LCO1490-JJ & 5'-CHA CW AAY CAT AAA GAT ATY GG-3‘ & $\mathrm{COI}$ & $\mathrm{x}$ & $\mathrm{x}$ & Folmer et al. 1994 \\
\hline HCO2198-JJ & $5^{\circ}$-AWA CTT CVG GRT GVC CAA ARA ATC A-3“ & $\mathrm{COI}$ & $\mathrm{x}$ & $\mathrm{x}$ & Folmer et al. 1994 \\
\hline Niph15 & 5'-CAA GTA CCG TGA GGG AAA GTT-3’ & $28 \mathrm{~S}$ & $\mathrm{x}$ & & Verovnik et al. 2005 \\
\hline Niph15i & $5^{\circ}$-AGA GTC AAA AGA CCG TGA AAC C-3 ‘ & $28 \mathrm{~S}$ & & $\mathrm{x}$ & present publication \\
\hline Niph16 & 5'-AGG GAA ACT TCG GAG GGA ACC-3‘ & $28 \mathrm{~S}$ & $\mathrm{x}$ & & Verovnik et al. 2005 \\
\hline Niph16i & 5'-GAT TGG TCT TTC GCC CCT AT-3' & $28 \mathrm{~S}$ & & $\mathrm{x}$ & present publication \\
\hline Niph20 & 5‘-AAA CAC GGG CCA AGG AGT AT-3‘ & $28 \mathrm{~S}$ & & $\mathrm{x}$ & Flot et al. 2010b \\
\hline Niph21 & 5'-TAT ACT CCT TGG CCC GTG TT-3“ & $28 \mathrm{~S}$ & & $\mathrm{x}$ & Flot et al. 2010b \\
\hline
\end{tabular}

sediment and specimens into the water column. The collected specimens were immediately preserved in $96 \%$ ethanol and kept at $-20^{\circ} \mathrm{C}$ until DNA was isolated.

Due to the small size of M. leruthi, we used one entire specimen for each DNA isolation. DNA was extracted following the standard protocol of the NucleoSpin ${ }^{\circledR}$ Tissue Kit (Macherey-Nagel) except that we performed two elution steps, the first one with $60 \mu \mathrm{L}$ and the second with $40 \mu \mathrm{L}$ (instead of a single elution step with $100 \mu \mathrm{L}$ ) to achieve a higher concentration of DNA. The resulting DNA isolates are stored at $-20^{\circ} \mathrm{C}$ in the collections of the Evolutionary Biology \& Ecology research unit at the Université libre de Bruxelles (ULB).

The Folmer fragment of the cytochrome $c$ oxidase subunit 1 (COI) gene was amplified via polymerase chain reaction (PCR) (FOLMER et al. 1994) using the primers HCO2198-JJ and LCO1490-JJ (ASTRIN $\&$ STÜBEN 2008; see Table 2). The PCR mix contained $1 \mu$ L DNA template (variable concentration), $0.8 \mu \mathrm{L}$ of each primer $(10 \mathrm{pmol} / \mu \mathrm{L}), 5 \mu \mathrm{L}$ of DreamTaq DNA Polymerase (Thermo Scientific) and $2.4 \mu \mathrm{L}$ ultrapure water. PCR cycling conditions were an initial 3-min denaturation step at $94^{\circ} \mathrm{C}$ followed by 36 cycles of $20 \mathrm{~s}$ denaturation at $94^{\circ} \mathrm{C}, 45 \mathrm{~s}$ annealing at $50^{\circ} \mathrm{C}$, and $60 \mathrm{~s}$ extension at $65^{\circ} \mathrm{C}$; then a final 2 min elongation step at $65^{\circ} \mathrm{C}$.

We also sequenced Verovnik's fragment of the nuclear 28S ribosomal gene. The primers Niph15 and Niph16 (see Table 2) were used for amplification (VEROVNIK et al. 2005). The PCR mix for 28S contained $2 \mu \mathrm{L}$ of DNA template (variable concentration), $1 \mu \mathrm{l}$ of each primer $(10 \mathrm{pmol} / \mu \mathrm{L}), 0.2 \mu \mathrm{L}$ of REDTaq DNA Polymerase (Sigma-Aldrich), $5 \mu \mathrm{L}$ REDTaq reaction buffer and $15.8 \mu \mathrm{L}$ ultrapure water. PCR cycling conditions for $28 \mathrm{~S}$ were an initial $3 \mathrm{~min}$ denaturation step at $95^{\circ} \mathrm{C}$; followed by 56 cycles of $30 \mathrm{~s}$ denaturation at $94^{\circ} \mathrm{C}, 60 \mathrm{~s}$ annealing at $45^{\circ} \mathrm{C}$, and $90 \mathrm{~s}$ extension at $72^{\circ} \mathrm{C}$.

The amplification success of each PCR reaction was verified using agarose gel electrophoresis, then PCR products were sequenced at Genoscreen (Lille, France). For COI the primer used for sequencing were the same as for PCR amplification, whereas for $28 \mathrm{~S}$ we used the primers Niph20 and Niph21 (FLOT et al. 2010b) as well as one or both of two new internal primers located slightly inward of the primers used for initial amplification (Niph15i and Niph16i; see Table 2).

The resulting chromatograms were assembled and cleaned using Sequencher version 4.1.4 (Gene Codes, USA). Whenever double peaks were observed in both the forward and reverse chromatograms of an 
individual, we considered this individual as polymorphic and called its two haplotypes (determined using the approach summarized in FONTANETO et al. 2015) "a" and "b" in downstream analyses.

\section{Phylogenetic and species delimitation analyses}

We compiled comprehensive sets of COI and 28S including all sequences available in GenBank to date, then curated them manually to remove duplicates. The resulting set of $1384 \mathrm{COI}$ sequences was aligned manually, whereas for the 255 sequences of $28 \mathrm{~S}$ (including two gammarids Gammarus fossarum and Gammarus pulex and two crangonyctids Crangonyx subterraneus and Synurella ambulans as outgroups) we used MAFFT 7's E-INS-i mode (KATOH et al. 2019).

The comprehensive 28S alignment was used to reconstruct a global phylogeny of niphargid and pseudoniphargid amphipods. The best-fit substitution model, selected using ModelFinder (KALYAANAMOORTHY et al. 2017) according to the Bayesian Information Criterion (SCHWARZ 1978), was GTR+F+I+G4 (codes follow the IQTREE manual). Phylogenetic relationships were reconstructed using maximum likelihood with 1,000 ultrafast bootstrap replicates (HOANG et al. 2018) in IQ-TREE 2 (MINH et al. 2020); 253 out of 255 sequences (including all Microniphargus sequences) passed the gap/ ambiguity test in IQTree 2 and were used in the analysis.

The comprehensive COI alignment was analysed using ABGD (Automatic Barcode Gap Discovery, available online at https://bioinfo.mnhn.fr/abi/public/abgd/), a distance-based species delimitation tool (PUILlAndRE et al. 2012) that first attempts to infer the most likely position of a barcode gap ('initial partitioning') before conducting a second round of splitting by recursively applying the same procedure on the groups defined during the first step ('recursive partitioning'). ABGD was run on the public webserver with default parameters.

A subset of the COI sequences (comprising all new Microniphargus sequences, all high-quality, complete Pseudoniphargus COI sequences inferred from complete mitochondrial genome sequences from BAUZÀ-RIBOT et al. (2012) and STOKKAN et al. $(2016,2018)$ plus two sequences of Niphargus and sequences of the Crangonyctidae Crangonyx subterraneus and Synurella ambulans (as outgroups) was used to build a ML tree using IQ-TREE 2 with the same modalities illustrated for 28S; the best-fit substitution model, selected using ModelFinder (according to the Bayesian Information Criterion was $\mathrm{TIM}+\mathrm{F}+\mathrm{I}+\mathrm{G} 4$ (codes follow the IQTREE manual).

Phylogenetic networks were built for the COI and 28S sequences obtained from Microniphargus using HaplowebMaker (SPÖRI \& FLOT 2020, available online from https://eeg-ebe.github.io/ HaplowebMaker/). Average genetic distances between Microniphargus sequences identified as belonging to different lineages were computed in MEGA X (KUMAR et al. 2018) using uncorrected p-distances. A K/A species delimitation analysis (BIRKY et al. 2010; SCHÖN et al. 2012; BIRKY 2013) was performed on the COI sequences of Microniphargus using the online program KoT with a $\mathrm{K} / \theta$ threshold value of 6 (corresponding to a p-value $<0.01$; SPÖRI et al. 2021, available online from https://eeg-ebe.github.io/ KoT).

\section{Results}

For both COI and 28S, we successfully sequenced nine Microniphargus leruthi specimens. For COI, four individuals (one from Belgium and two from England) displayed one double peak each and were therefore represented by two sequences ' $a$ ' and ' $b$ ' (with a single base difference between them) in all downstream analyses. One $M$. leruthi individual (from Belgium) displayed a double peak in its $28 \mathrm{~S}$ chromatograms and was therefore represented by two sequences (with a single base difference between them) in all downstream analyses, whereas all other individuals were homozygous for the 28S marker (Fig. 2). 

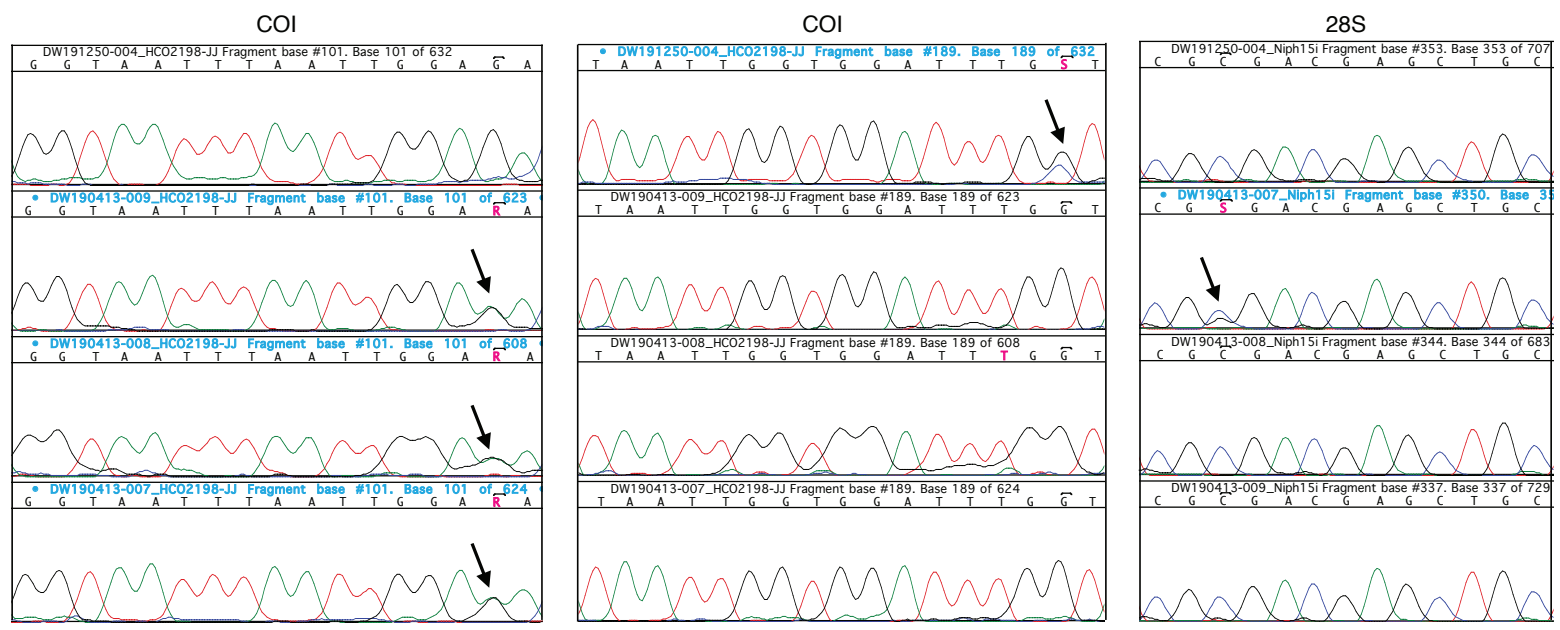

Figure 2 - Screenshots of the Sequencher program showing the double peaks identified in the COI (left and middle panel) and 28S (right panel) chromatograms.

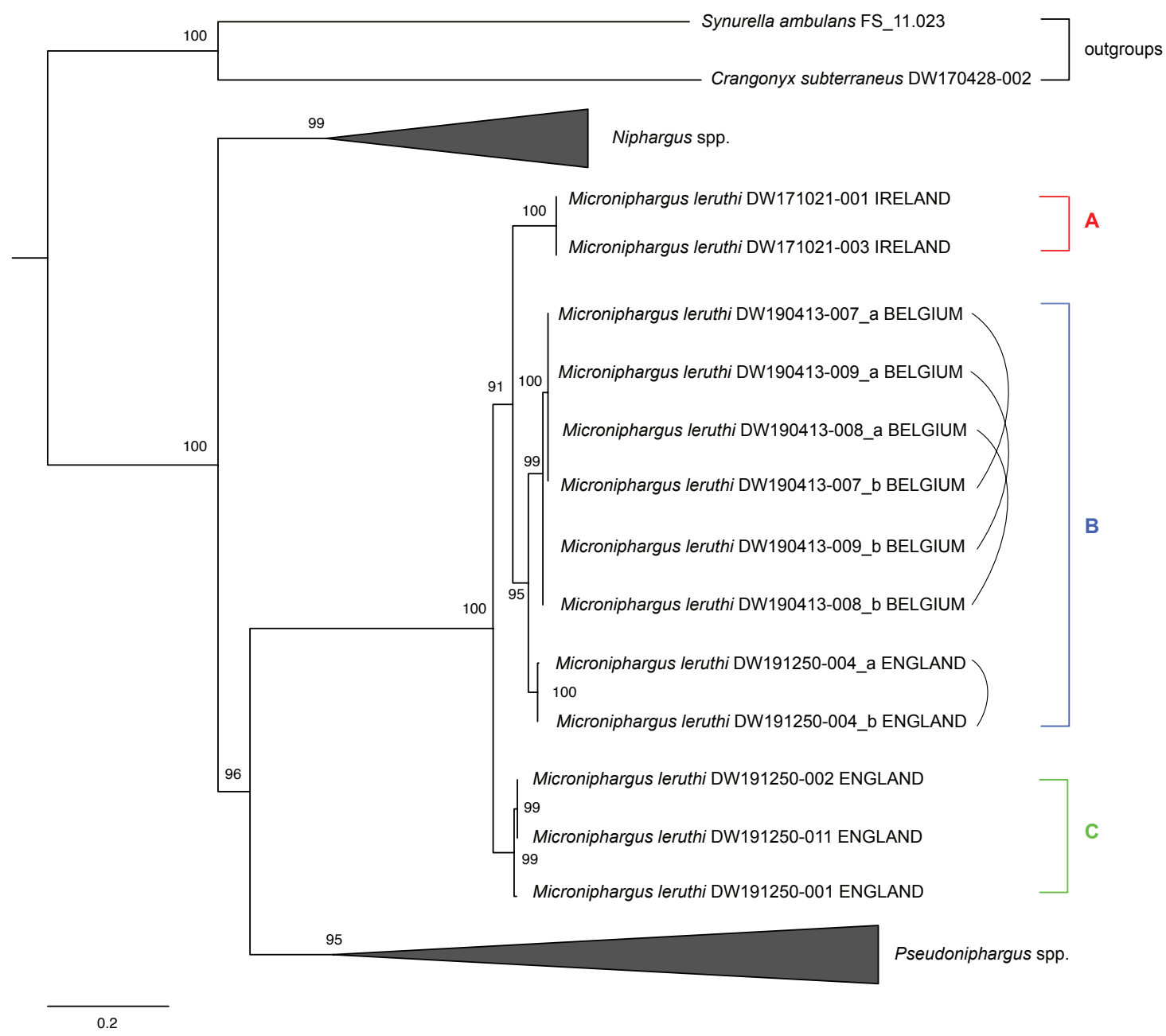

Figure 3 - COI maximum-likelihood phylogeny of Microniphargus and Pseudoniphargus (with two Niphargus and two crangonyctids as outgroups). The tree was turned into a haploweb by adding connections between haplotypes found co-occurring in the same individual. 


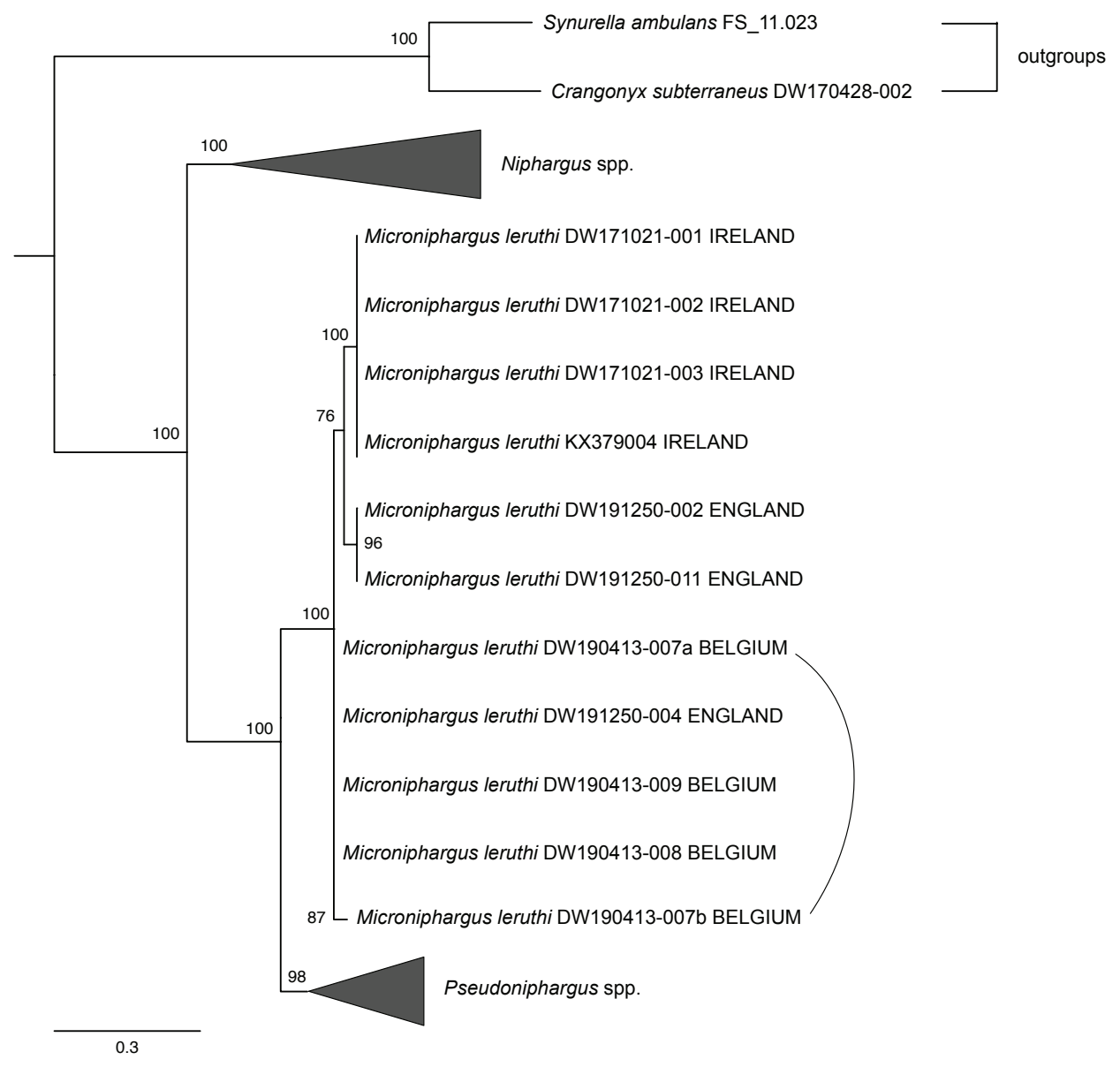

Figure $4-28$ S maximum-likelihood phylogeny of Microniphargus, Niphargus and Pseudoniphargus (with two crangonyctids as outgroups). The tree was turned into a haploweb by adding connections between haplotypes found co-occurring in the same individual.

The COI phylogeny supported a (Microniphargus + Pseudoniphargus) clade with $96 \%$ of ultrafast bootstrap replicates (Fig. 3 and Fig. S1) and revealed Microniphargus to be composed of three main clades A (found only in Ireland), B (found both in Belgium and in England) and C (found only in England), with $>99 \%$ ultrafast bootstrap support for each of them. Clade B contained two subclades comprising respectively Belgian and English sequences, also with $>99 \%$ ultrafast bootstrap support. Clade B and $\mathrm{C}$ co-occurred at one sampling site (Fig. 1). The sister-clade relationship between Pseudoniphargus and Microniphargus was supported with $100 \%$ of ultrafast bootstrap replicates in the comprehensive $28 \mathrm{~S}$ phylogeny, which supported also the monophyly of lineages A and C (with $100 \%$ and $96 \%$ bootstrap replicates, respectively) but not of B, which was paraphyletic using this marker (Fig. 4 and Fig. S2).

The COI lineages A, B and C were separated by average p-distances of $0.073-0.081$ between $\mathrm{A}$ and $\mathrm{B}, 0.072$ between $\mathrm{A}$ and $\mathrm{C}$, and 0.066 between $\mathrm{B}$ and $\mathrm{C}$; whereas the p-distance between the two sublineages of B was 0.029. ABGD's initial partitioning of our comprehensive COI dataset supported a three-species hypothesis for Microniphargus leruthi, whereas the recursive partitioning favoured a fourspecies hypothesis separating the Belgian and English sub-lineage of lineage C. The KoT analysis of 


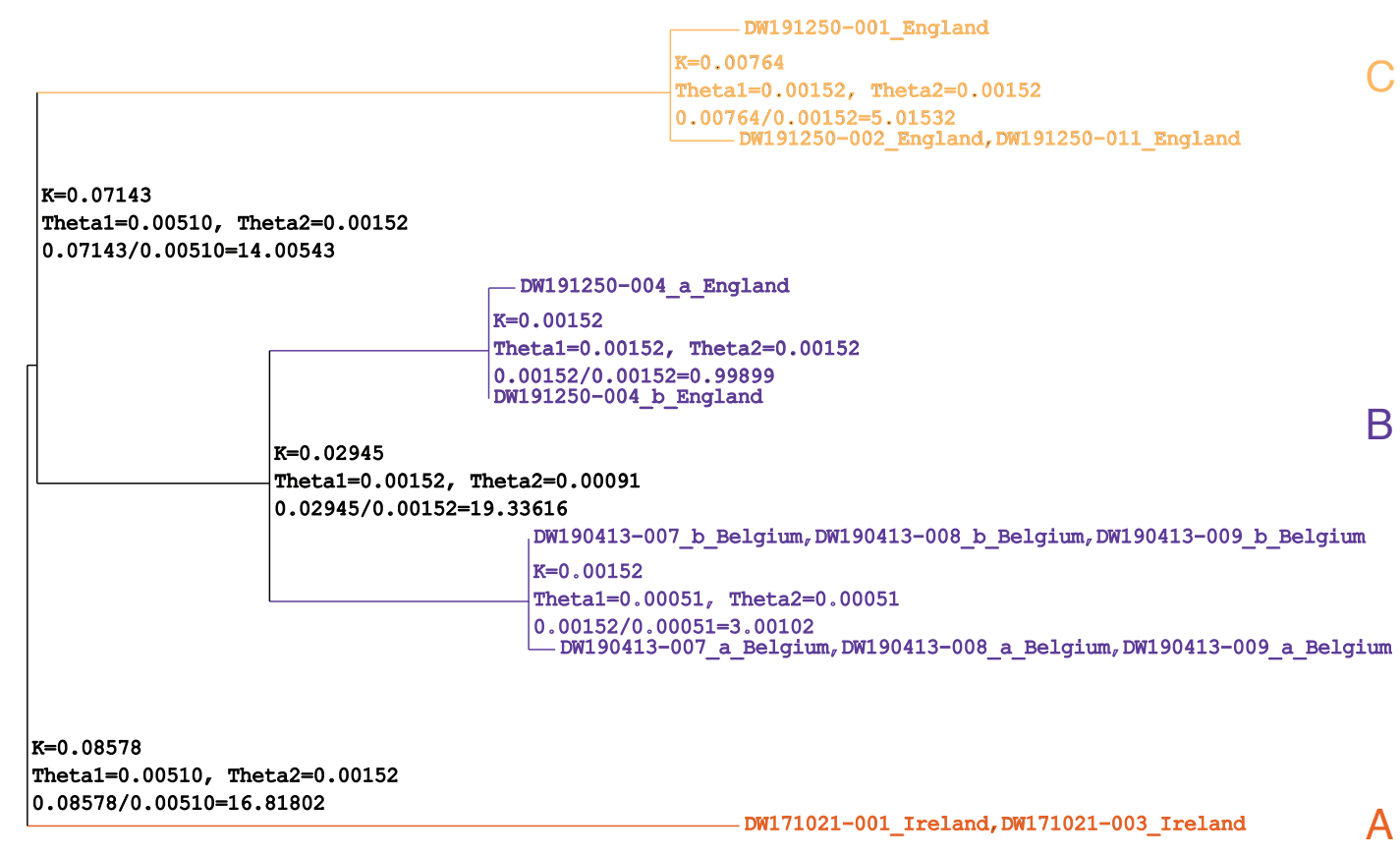

Figure 5 - Output of the program KoT applying the K/ $\theta$ method for species delimitation to the Microniphargus COI dataset. At each node are shown the average (Jukes-Cantor corrected) distance K between the corresponding sister clades, Watterson's estimator of genetic diversity $\theta$ of each of the two clades, and the ratio of $\mathrm{K}$ divided by the largest of the two $\theta$ values (for details of the method see Spöri et al. 2021). Species were delimited using a threshold $\mathrm{K} / \theta$ value of 6 , i.e. sister clades exhibiting $\mathrm{K} / \theta$ ratios greater than 6 were considered as putative distinct species.

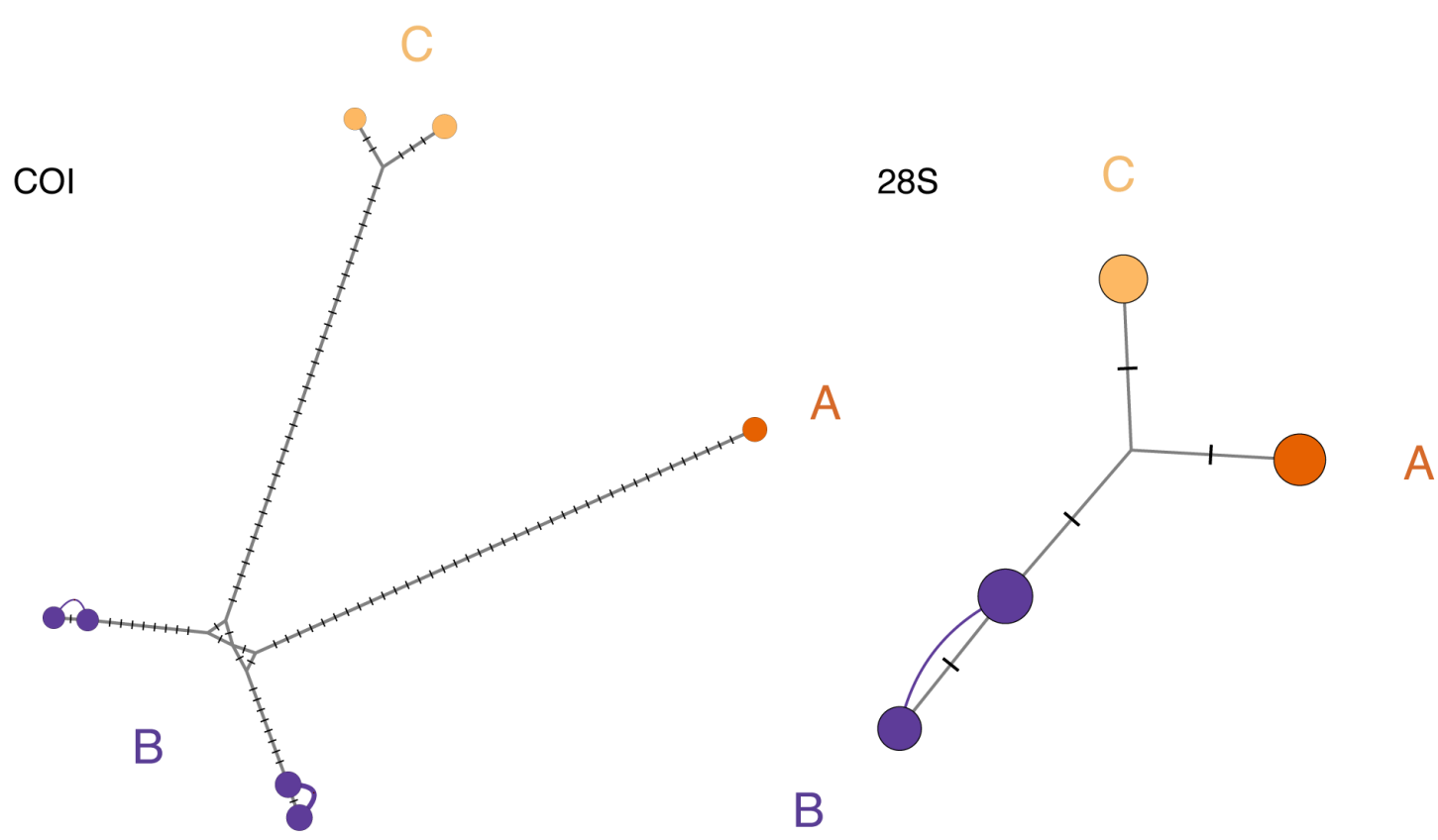

Figure 6 - Median-joining networks of the Microniphargus COI and 28S sequences obtained in the present study. The networks were turned into haplowebs by adding connections between haplotypes found co-occurring in the same individual. 
the Microniphargus COI sequences supported a four-species scenario as well, with a K/ $\theta$ ratio of 19.3 between the two subclades within lineage $B$, itself separated by a gap with a $K / \theta$ of 14.0 from lineage $\mathrm{C}$, and finally separated by a gap with a $\mathrm{K} / \theta$ ratio of 16.8 from lineage A (Fig. 5). By contrast, the 28S haploweb revealed three fields for recombination (FFRs sensu DOYLE 1995, i.e., putative species following the criterion of mutual allelic exclusivity; FLOT et al. 2010a), corresponding to clades A, B and C (Fig. 6).

\section{Discussion}

\section{Key novel, high-quality sequences were acquired}

Our newly collected sequences include the first COI sequences of Microniphargus leruthi (and of Crangonyx subterraneus) made available to date, as well as new $28 \mathrm{~S}$ sequences that significantly improve the currently available sequences for these two species: the single Verovnik $28 \mathrm{~S}$ fragment sequence available till now for C. subterraneus (EU693288; FIŠER et al. 2008) is 100\% identical to ours (except for one obvious error at position 25), but its last $140 \mathrm{bp}$ are lacking; the single $28 \mathrm{~S}$ sequence of $M$. leruthi previously published (KX379004.1; FIŠER et al. 2017) is 100\% identical to our complete sequences from Ireland, but with the first $59 \mathrm{bp}$ and last 156 bp lacking; whereas the three Pseudoniphargus sequences available till now were also highly incomplete. The high-quality $28 \mathrm{~S}$ and COI sequences we obtained from representative individuals of $C$. subterraneus from Germany, Pseudoniphargus italicus from Sicily and P. spiniferus from Basses Pyrénées in France, as well as from each of the three lineages of $M$. leruthi identified in our study, will make it easier to include these species as outgroups in future studies of Niphargus, Pseudoniphargus and other related genera.

\section{Both COI and 28S sequences of Microniphargus were found to contain double peaks}

Out of the nine M. leruthi individuals whose COI marker was sequenced, four (three from Belgium and one from England) presented a double peak in their COI chromatograms, resulting in an intraindividual polymorphism level of $0.15 \%$ in these individuals. For the three Belgian specimens the double peak was an $\mathrm{R}=\mathrm{A}$ or $\mathrm{G}$ transition in position 101, whereas for the English specimen it was an $\mathrm{S}=\mathrm{C}$ or $\mathrm{G}$ transversion in position 189 (Fig. 4). These mutations were not synonymous but corresponded to $\mathrm{N}$ (asparagine) $\leftrightarrow \mathrm{D}$ (aspartate) and A (alanine) $\leftrightarrow \mathrm{G}$ (glycine) mutations in the translation amino acid sequences. Such mitochondrial double peaks are rare in niphargids: for instance, no double peak was observed in the COI chromatograms of the 67 Romanian specimens sequenced in FLOT et al. (2014) nor reported for any of the hundreds of niphargids sequenced in EME et al. (2018). The presence of two distinct COI sequences in $M$. leruthi individuals may be the result of heteroplasmy, i.e., the presence of two distinct mitochondrial lineages in the cells of an organism, or of a recent numt, i.e., a nuclear pseudogene of a mitochondrial sequence following the transfer and integration of a copy of this sequence in a nuclear chromosome (DIERCKXSENS et al. 2020). Determining which one of these two hypotheses is correct in the present case will require whole-genome sequencing, which is beyond the scope of the present study, but in any case, the very limited divergence between the COI sequences found cooccurring in some individuals (with a single double peak per individual) did not hinder downstream phylogenetic analyses.

\section{The genus Microniphargus is more closely related to Pseudoniphargus than to Niphargus}

Our COI and 28S phylogenetic trees confirm that all collected specimens assigned to the morphospecies Microniphargus leruthi form a monophyletic group that is clearly distinct from Niphargus and Pseudoniphargus, thereby confirming its status as a separate genus previously established on the sole basis of morphological characters (SCHELLENBERG 1934). The results of our analysis confirm the 
conclusions reached by MOŠKRIČ \& VEROVNIK (2019) and COPILAŞ-CIOCIANU et al. (2020) on the close affinity between Microniphargus and Pseudoniphargus, suggesting the inclusion of the genus Microniphargus within the family Pseudoniphargidae to avoid paraphyly of Niphargidae. Consequently, superfamilies Allocrangonyctoidea and Crangonyctoidea as proposed by LOWRY \& MYERS (2013, 2017) turn out to be paraphyletic.

As mentioned in the introduction, a similarity between the two genera can be found in the shape of the telson (which is widely incised and carries one spine on each lobe), and also partly the shape of gnathopod 1. This shape of telson as well as the protrusion on the carpus of gnathopod 1 are found also in Bogidiellidae (another family placed in recent phylogenetic trees not far away from the clade Niphargidae+Pseudoniphargidae: COPILAȘ-CIOCIANU et al. 2020) and may be simply symplesiomorphic, in which case the deeply incised, bilobated telson of Niphargus would represent an apomorphic character of this genus. However, the small size of Microniphargus, the reduced setation of mandibular palp and gnathopods, the lack of elongation of the third uropod in males, and the 1-articulated accessory flagellum of antennulae suggest a major role of paedomorphosis, making it difficult or impossible to correctly allocate this genus within current amphipod taxonomy and phylogeny based on morphological characters alone.

The inclusion of Microniphargus within Pseudoniphargidae requires an adjustment in the diagnosis of the family, recently revised by LOWRY \& MYERS (2013), with minor changes as follows:

Body depigmented, eyes absent. Antenna 1 longer than antenna 2; accessory flagellum short, or minute, 1-2 articulated. Gnathopod 1 smaller (or weaker) than gnathopod 2; propodus with multiple groups of simple or bifid setae along palmar margin. Urosomites 1 to 3 free, without robust dorsal setae. Urosomite 1 without distoventral robust seta. Uropod 3 biramous; inner ramus minute; outer ramus article 2 absent. Telson notched, distal margin emarginate or nearly straight, with 1-3 robust spines on each lobe.

\section{Microniphargus leruthi comprises at least three cryptic lineages}

Our COI phylogeny, ABGD's initial partitioning of our comprehensive COI dataset and our haploweb analysis of $28 \mathrm{~S}$ sequences of Microniphargus support the hypothesis that Microniphargus leruthi is composed of three distinct, putatively species-level lineages: clade A found in Ireland, clade B found both in England and in Belgium (with two COI sub-clades consistent with the geographic distance between these two locations), and clade C found so far only in England. By contrast, ABGD's recursive partitioning supports a four-species hypothesis, and so does the KoT analysis. However, the p-distances between the three main lineages A, B and C are all well above the 3\% species-level threshold traditionally considered in barcoding studies (HEBERT et al. 2003), whereas the average p-distance between the two COI sub-clades of B falls below this symbolic threshold. These arguments, together with the fact that all individuals of lineage B (and only these individuals) display double peaks in their COI chromatograms, lead us to consider tentatively the two sub-clades of lineage B as conspecific and therefore to distinguish at present only three putative species-level lineages within M. leruthi.

Although lineage A (found only in Ireland to date) appears geographically separated from the other two, lineages B and C occur in sympatry in at least one location (Swildon's Hole in Somerset), bringing further support to the hypothesis that these two lineages are distinct species. The phylogenetic analysis based on COI could point to an origin of the genus Microniphargus in England with subsequent dispersals to Ireland and to Belgium; however, more samples and analyses will be required to test this hypothesis. The fact that lineage B still occurs on both sides of the English Channel is not overly surprising since the land connection between England and continental Europe was only severed about 8,000 years ago (WALLER \& LONG 2003). 
The hypothesis that the three Microniphargus leruthi lineages identified here represent distinct cryptic (or pseudo-cryptic) species will need to be tested further. Doing so will require further collecting and sequencing, as well as detailed morphological analyses using microscopy techniques appropriate for such small specimens.

\section{Acknowledgements}

Thanks to John Boulton and Camille Ek for helping with fieldwork and collecting. Molecular analyses were supported by the Belgian Fonds de la Recherche Scientifique (FNRS) via research credit J.0272.17 and by the Fédération Wallonie-Bruxelles via an 'Action de Recherche Concertée' (ARC) grant, both to Jean-François Flot.

\section{References}

ARNSCHEIDT J., HAHN H.J. \& FUCHS A. (2008). Aquatic subterranean Crustacea in Ireland: results and new records from a pilot study. Cave and Karst Science 35 (1): 53-58.

AstRIN J.J. \& STÜBEN P.E. (2008). Phylogeny in cryptic weevils: molecules, morphology and new genera of western Palaearctic Cryptorhynchinae (Coleoptera: Curculionidae). Invertebrate Systematics 22 (5): 503-522. https://doi.org/10.1071/IS07057

BauzÀ -Ribot M.M., Juan C., Nardi F., Oromi P., Pons J. \& Jaume D. (2012). Mitogenomic phylogenetic analysis supports continental-scale vicariance in subterranean thalassoid crustaceans. Current Biology 22: 2069-2074. https://doi.org/10.1016/j.cub.2012.09.012

BIRKY C.W. (2013). Species detection and identification in sexual organisms using population genetic theory and DNA sequences. PLOS ONE 8: e52544. https://doi.org/10.1371/journal.pone.0052544

Birky C.W., ADAms J., Gemmel M. \& PerRY J. (2010). Using population genetic theory and DNA sequences for species detection and identification in asexual organisms. PLoS ONE 5: e10609. https://doi.org/10.1371/journal.pone.0010609

Borko Š., Collette M., Brad T., ZAKŠEK V., Flot J.-F., VAXevanopoulos M., SARbu S.M. \& FIŠER C. (2019). Amphipods in a Greek cave with sulphidic and non-sulphidic water: phylogenetically clustered and ecologically divergent. Systematics and Biodiversity 17 (6): 558-572. https://doi.org/10.1080/14772000.2019.1670273

Copilaș-Ciocianu D., Fišer C., Borza P., Balázs G., Angyal D. \& Petrusek A. (2017). Low intraspecific genetic divergence and weak niche differentiation despite wide ranges and extensive sympatry in two epigean Niphargus species (Crustacea: Amphipoda). Zoological Journal of the Linnean Society 181 (3): 485-499. https://doi.org/10.1093/zoolinnean/zlw031

COPILAŞ-CIOCIANU D., BORKO Š. \& FišER C. (2020). The late blooming amphipods: global change promoted post-Jurassic ecological radiation despite Palaeozoic origin. Molecular Phylogenetics and Evolution 143: 106664. https://doi.org/10.1016/j.ympev.2019.106664

DELhez F., DETHIER M. \& HuBART J.-M. (1999). Contribution à la connaissance de la faune des grottes de la Wallonie. Bulletin des Chercheurs de la Wallonie 39: 27-54.

DiERCKXSENS N., MARDULYN P. \& SMits G. (2020). Unraveling heteroplasmy patterns with NOVOPlasty. NAR Genomics and Bioinformatics 2 (1): lqz011. https://doi.org/10.1093/nargab/lqz011

Dobreanu E. \& Manolache C. 1933. Zur Kenntnis der Amphipodenfauna Rumäniens. Notationes Biologicae 1 (3): 102-108. 
DOYLE J.J. (1995). The irrelevance of allele tree topologies for species delimitation, and a non-topological alternative. Systematic Botany 20 (4): 574-588. https://doi.org/10.2307/2419811

Eme D., Zagmajster M., Delić T., Fišer C., Flot J.-F., Konecny-Dupré L., PÁlsson S., Stoch F., ZAKŠEK V., DOUADY C.J. \& MALARD F. (2018). Do cryptic species matter in macroecology? Sequencing European groundwater crustaceans yields smaller ranges but does not challenge biodiversity determinants. Ecography 41 (2): 424-436. https://doi.org/10.1111/ecog.02683

FišEr C., Konec M., Alther R., Švara V. \& Altermatt F. (2017). Taxonomic, phylogenetic and ecological diversity of Niphargus (Amphipoda: Crustacea) in the Hölloch cave system (Switzerland). Systematics and Biodiversity 15 (3): 218-237. https://doi.org/10.1080/14772000.2016.1249112

FiŠER C., SKet B. \& TRONTELJ P. (2008). A phylogenetic perspective on 160 years of troubled taxonomy of Niphargus (Crustacea: Amphipoda). Zoologica Scripta 37 (6): 665-680.

https://doi.org/10.1111/j.1463-6409.2008.00347.x

Flot J.-F., Couloux A. \& Tillier S. (2010a). Haplowebs as a graphical tool for delimiting species: a revival of Doyle's 'field for recombination' approach and its application to the coral genus Pocillopora in Clipperton. BMC Evolutionary Biology 10: 372. https://doi.org/10.1186/1471-2148-10-372

FLOT J.-F., WÖRHEIDE G. \& DATTAGUPTA S. (2010b). Unsuspected diversity of Niphargus amphipods in the chemoautotrophic cave ecosystem of Frasassi, central Italy. BMC Evolutionary Biology 10: 171. https://doi.org/10.1186/1471-2148-10-171

Flot J.-F., BAuermeister J., Brad T., Hillebrand-Voiculescu A., SARbu S.M., Dattagupta S. (2014). Niphargus-Thiothrix associations may be widespread in sulphidic groundwater ecosystems: evidence from southeastern Romania. Molecular Ecology 23 (6): 1405-1417. https://doi.org/10.1111/mec.12461

Folmer O., Black M., HoeH W., Lutz R. \& VRIJENHOEK R. (1994). DNA primers for amplification of mitochondrial cytochrome $c$ oxidase subunit I from diverse metazoan invertebrates. Molecular Marine Biology and Biotechnology 3 (5): 294-299.

Fontaneto D., Flot J.-F. \& TANG C.Q. (2015). Guidelines for DNA taxonomy, with a focus on the meiofauna. Marine Biodiversity 45: 433-451. https://doi.org/10.1007/s12526-015-0319-7

FuCHS A. (2007). Erhebung und Beschreibung der Grundwasserfauna in Baden-Württemberg. Thesis, Koblenz-Landau.

Hebert P.D.N., Cywinska A., BAll S.L. \& DE WAARD J.R. (2003). Biological identifications through DNA barcodes. Proceedings of the Royal Society. Biological Sciences 270: 313-321. https://doi.org/10.1098/rspb.2002.2218

HoAng D.T., Chernomor O., von HAESEler A., Minh B.Q. \& Vinh L.S. (2018). UFBoot2: improving the ultrafast bootstrap approximation. Molecular Biology and Evolution 35: 518-522.

https://doi.org/10.1093/molbev/msx281

Hoffmann J. (1963). Faune des Amphipodes du Grand-Duché de Luxembourg. Archives de la Section des Sciences de l'Institut Grand-Ducal Nouvelle Série 29: 77-128.

Jurado-Rivera J.A., Álvarez G., Caro J.A., Juan C., Pons J. \& Jaume D. (2017). Molecular systematics of Haploginglymus, a genus of subterranean amphipods endemic to the Iberian Peninsula (Amphipoda: Niphargidae). Contributions to Zoology 86 (3): 239-260.

https://doi.org/10.1163/18759866-08603004

KalyaAnamoorthy S., Minh B., Wong T., von Haeseler A. \& Jermin L.S. (2017). ModelFinder: fast model selection for accurate phylogenetic estimates. Nature Methods 14: 587-589. https://doi.org/10.1038/nmeth.4285 
KaRAman G.S. \& RufFo S. (1986). Amphipoda: Niphargus-group (Niphargidae sensu Bousfield, 1982). In: BotoseAnU L. (ed.) Stygofauna mundi. A Faunistic, Distributional, and Ecological Synthesis of the World Fauna inhabiting Subterranean Waters (including the Marine Interstitial): 514-534. Brill, Leiden.

KATOH K., ROZEWICKI J. \& YAMADA K.D. (2019). MAFFT online service: multiple sequence alignment, interactive sequence choice and visualization. Briefings in Bioinformatics 20 (4): 1160-1166. https://doi.org/10.1093/bib/bbx108

KNIGHT L.R.F.D. \& GLEDHILL T. (2010). The discovery of Microniphargus leruthi Schellenberg, 1934 (Crustacea: Amphipoda: Niphargidae) in Britain and its distribution in the British Isles. Zootaxa 2655 (1): 52-56. https://doi.org/10.11646/zootaxa.2655.1.3

KNight L.R.F.D. \& PenK M. (2010). Groundwater Crustacea of Ireland: a survey of the stygobitic Malacostraca in caves and springs. Biology \& Environment Proceedings of the Royal Irish Academy 110 (3): 211-235. https://doi.org/10.3318/BIOE.2010.110.3.211

Kumar S., Stecher G., Li M., Knyaz C. \& TAmura K. (2018). MEGA X: Molecular Evolutionary Genetics Analysis across Computing Platforms. Molecular Biology and Evolution 35 (6): 1547-1549. https://doi.org/10.1093/molbev/msy096

Lefébure T., Douady C.J., Gouy M., Trontelj P., Briolay J. \& Gibert J. (2006). Phylogeography of a subterranean amphipod reveals cryptic diversity and dynamic evolution in extreme environments. Molecular Ecology 15: 1797-1806. https://doi.org/10.1111/j.1365-294X.2006.02888.x

LERUTH R. (1939). La biologie du domaine souterrain et la faune cavernicole de la Belgique. Mémoire du Musée royal d'Histoire naturelle de Belgique 87: 1-506.

LOWRY J.K. \& MYERS A.A. (2013). A phylogeny and classification of the Senticaudata subord. nov. (Crustacea: Amphipoda). Zootaxa 3610 (1): 1-80. https://doi.org/10.11646/zootaxa.3610.1.1

LOWRY J.K. \& MYers A.A. (2017). A phylogeny and classification of the Amphipoda with the establishment of the new order Ingolfiellida (Crustacea: Peracarida). Zootaxa 4265 (1): 1-89. https://doi.org/10.11646/zootaxa.4265.1.1

Matzke D., Fuchs A., Berkhoff S., Bork J. \& HAhn H.-J. (2009). Erhebung und Bewertung der Grundwasserfauna Sachen-Anhalts. Institut für Grundwasserökologie GbR, Im Niederfeld 15, 76829 Landau, Landau.

Mcinerney C.E., Maurice L., Robertson A.L., Knight L.R.F.D., Arnscheidt J., VenditTi C., Dooley J.S.G., Mathers T., Matthijs S., Erikkson K., Proudlove G.S. \& HÄnfling B. (2014). The Ancient Britons: groundwater fauna survived extreme climate changes over tens of millions of years across NW Europe. Molecular Ecology 23: 1153-1166. https://doi.org/10.1111/mec.12664

Minh B.Q., Schmidt H.A., Chernomor O., Schrempf D., Woodhams M.D., von Haeseler A., LANFEAR R. (2020). IQ-TREE 2: new models and efficient methods for phylogenetic inference in the genomic era. Molecular Biology and Evolution 37: 1530-1534. https://doi.org/10.1093/molbev/msaa015

MOŠKRIČ A. \& VEROVNIK R. (2019). Five nuclear protein-coding markers for establishing a robust phylogenetic framework of niphargid crustaceans (Niphargidae: Amphipoda) and new molecular sequence data. Data in Brief 25: 104134. https://doi.org/10.1016/j.dib.2019.104134

NotenBoOM J. (1988). Parapseudoniphargus baetis, new genus, new species, a stygobiont amphipod crustacean from the Guadalquivir river basin (southern Spain), with phylogenetic implications. Journal of Crustacean Biology 8: 110-121. https://doi.org/10.1163/193724088X00134 
Puillandre N., Lambert A., Brouillet S. \& Achaz G. (2012). ABGD, Automatic Barcode Gap Discovery for primary species delimitation. Molecular Ecology 21 (8): 1864-1877. https://doi.org/10.1111/j.1365-294X.2011.05239.x

SCHIÖDTE J.C. (1849). Specimen faunce subterraneae: bidrag til den underjordiske Fauna. Bianco Luno, Kjöbenhavn.

SCHELlENBERG A. (1934). Eine neue Amphipoden-Gattung aus einer belgischen Höhle, nebst Bemerkungen über die Gattung Crangonyx. Zoologischer Anzeiger 106 (9): 215-218.

Schön I., Pinto R.L., HALSE S., SMith A.J., MARTEns K. \& Birky C.W. (2012). Cryptic species in putative ancient asexual darwinulids (Crustacea, Ostracoda). PLoS ONE 7: e39844.

https://doi.org/10.1371/journal.pone.0039844

SCHWARZ G. (1978). Estimating the dimension of a model. The Annals of Statistics 6 (2): 461-464. https://doi.org/10.1214/aos/1176344136

SPANGENBeRG H.-J. (1973). Beitrag zur Faunistik von Höhlengewässern im Zechstein des Südharzes und Kyffhäusers. Hercynia Neue Folge, 10 (2): 143-160.

SPÖRI Y. \& FLOT J.-F. (2020). HaplowebMaker and CoMa: two web tools to delimit species using haplowebs and conspecificity matrices. Methods in Ecology and Evolution 11 (11): 1434-1438. https://doi.org/10.1111/2041-210X.13454

SPÖRI Y., STOCH F., DELliCOUR S., BIRKY C.W. \& FlOT J.-F. (2021). KoT: an automatic implementation of the K/ $\theta$ method for species delimitation. bioRxiv. https://doi.org/10.1101/2021.08.17.454531

Stein H., Griebler C., Berkhoff S., Matzke D., Fuchs A. \& Hahn H.J. (2012). Stygoregions - a promising approach to a bioregional classification of groundwater systems. Scientific Reports 2: 673. https://doi.org/10.1038/srep00673

Stokkan M., Jurado-Rivera J.A., Juan C., Jaume D. \& Pons J. (2016). Mitochondrial genome rearrangements at low taxonomic levels: three distinct mitogenome gene orders in the genus Pseudoniphargus (Crustacea: Amphipoda). Mitochondrial DNA Part A 27: 3579-3589. https://doi.org/10.3109/19401736.2015.1079821

StokKan M., JuRAdO-Rivera J.A., Oromí P., JuAn C., JAUME D. \& PONS J. (2018). Species delimitation and mitogenome phylogenetics in the subterranean genus Pseudoniphargus (Crustacea: Amphipoda). Molecular Phylogenetics and Evolution 127: 988-999. https://doi.org/10.1016/j.ympev.2018.07.002

Trontelu P., Douady C.J., Fišer C., Gibert J., GoričKi Š., Lefébure T., Sket B. \& ZakŠEK V. (2009). A molecular test for cryptic diversity in ground water: how large are the ranges of macrostygobionts? Freshwater Biology 54 (4): 727-744. https://doi.org/10.1111/j.1365-2427.2007.01877.x

VerovNik R., SKet B. \& TRONTELJ P. (2005). The colonization of Europe by the freshwater crustacean Asellus aquaticus (Crustacea: Isopoda) proceeded from ancient refugia and was directed by habitat connectivity. Molecular Ecology 14 (14): 4355-4369. https://doi.org/10.1111/j.1365-294X.2005.02745.x

WALLER M.P. \& LONG A.J. (2003). Holocene coastal evolution and sea-level change on the southern coast of England: a review. Journal of Quaternary Science 18 (3-4): 351-359. https://doi.org/10.1002/jqs.754

Manuscript received: 13 August 2020

Manuscript accepted: 18 October 2021

Published on: 8 December 2021

Branch editor: Tom Artois 


\section{Appendix}

\section{Supplementary figures and tables}

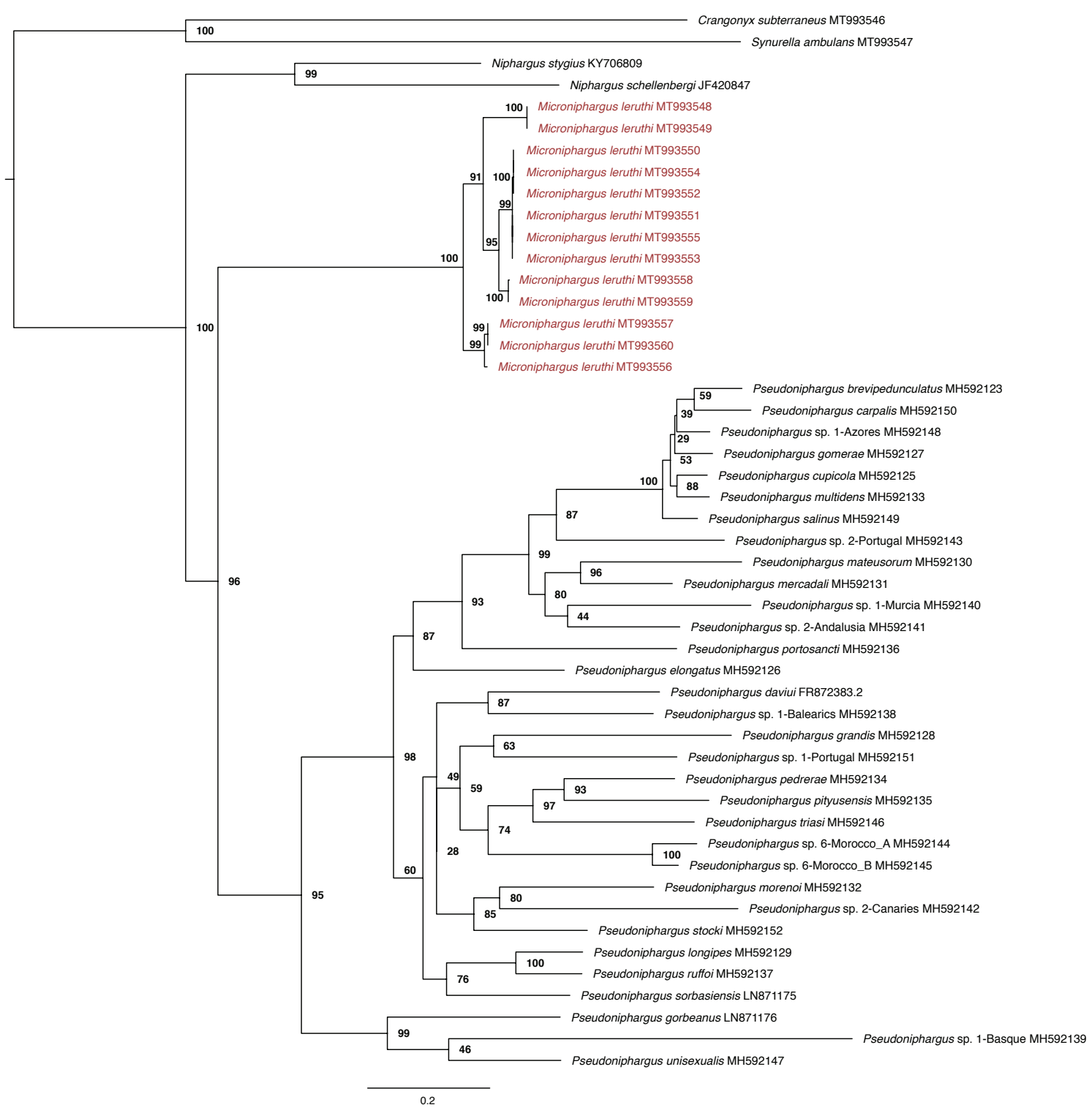

Figure S1 - Detailed version of the COI maximum-likelihood phylogeny. 


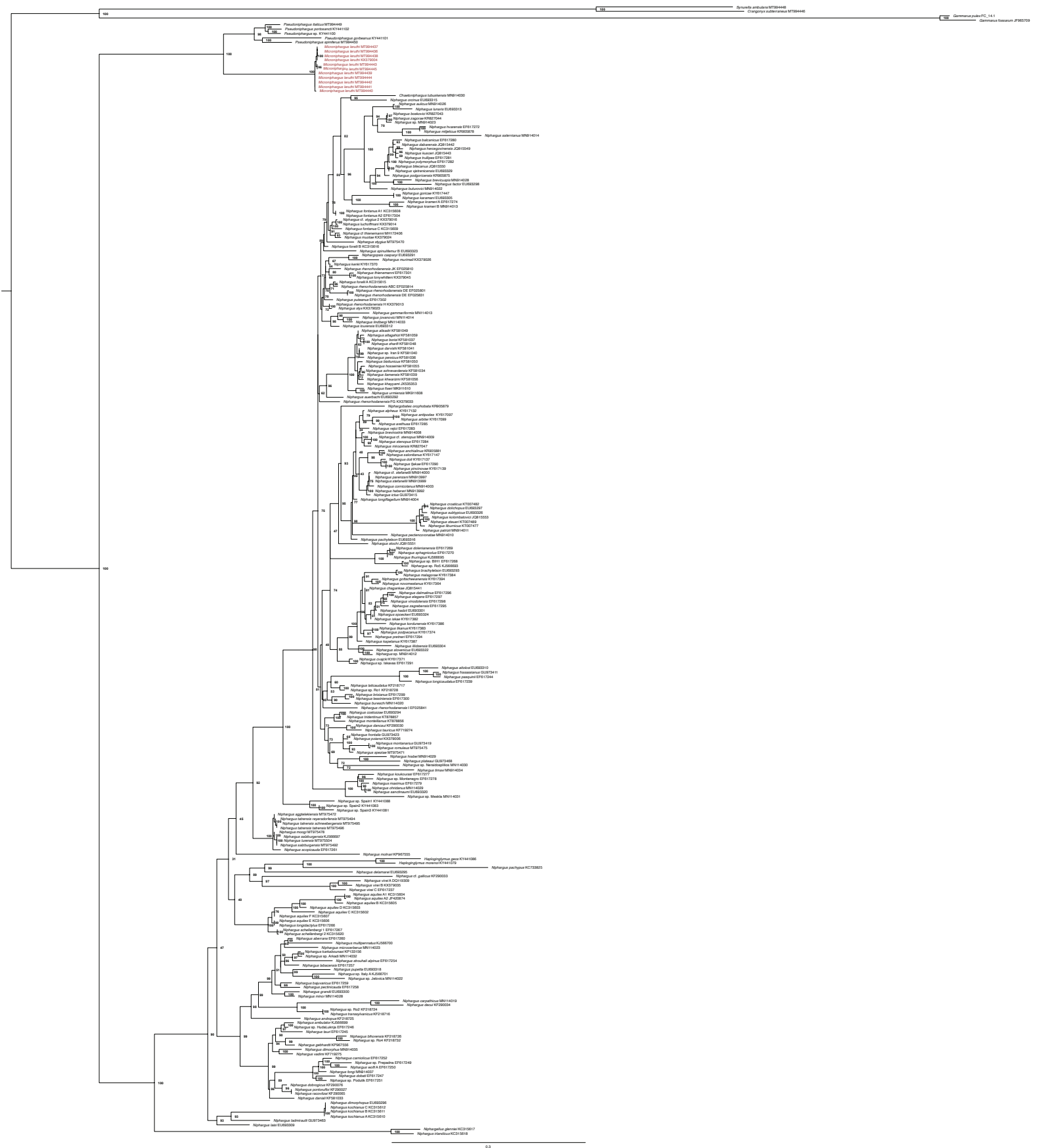

Figure S2 - Detailed version of the 28S maximum-likelihood phylogeny. 


\section{TABLE S1}

List of all the sequences included in the COI phylogeny, including species names and GenBank accession numbers.

\begin{tabular}{|c|c|c|}
\hline ID & Species & GB accession number \\
\hline 1 & Crangonyx subterraneus & MT993546 \\
\hline 2 & Synurella ambulans & МT993547 \\
\hline 3 & Niphargus stygius & KY706809 \\
\hline 4 & Niphargus schellenbergi & JF420847 \\
\hline 5 & Microniphargus leruthi A & МT993548 \\
\hline 6 & Microniphargus leruthi A & MT993549 \\
\hline 7 & Microniphargus leruthi $\mathrm{B}$ & MT993550 \\
\hline 8 & Microniphargus leruthi B & MT993551 \\
\hline 9 & Microniphargus leruthi B & MT993552 \\
\hline 10 & Microniphargus leruthi B & MT993553 \\
\hline 11 & Microniphargus leruthi B & МT993554 \\
\hline 12 & Microniphargus leruthi B & MT993555 \\
\hline 13 & Microniphargus leruthi $\mathrm{C}$ & MT993557 \\
\hline 14 & Microniphargus leruthi A & MT993558 \\
\hline 15 & Microniphargus leruthi A & MT993559 \\
\hline 16 & Microniphargus leruthi $\mathrm{C}$ & MT993560 \\
\hline 17 & Microniphargus leruthi $\mathrm{C}$ & MT993556 \\
\hline 18 & Pseudoniphargus brevipedunculatus & MH592123 \\
\hline 19 & Pseudoniphargus carpalis & MH592150 \\
\hline 20 & Pseudoniphargus cupicola & MH592125 \\
\hline 21 & Pseudoniphargus daviui & FR872383.2 \\
\hline 22 & Pseudoniphargus elongatus & MH592126 \\
\hline 23 & Pseudoniphargus gomerae & MH592127 \\
\hline 24 & Pseudoniphargus gorbeanus & LN871176 \\
\hline 25 & Pseudoniphargus grandis & MH592128 \\
\hline 26 & Pseudoniphargus longipes & MH592129 \\
\hline 27 & Pseudoniphargus mateusorum & MH592130 \\
\hline 28 & Pseudoniphargus mercadali & MH592131 \\
\hline 29 & Pseudoniphargus morenoi & MH592132 \\
\hline 30 & Pseudoniphargus multidens & MH592133 \\
\hline 31 & Pseudoniphargus pedrerae & MH592134 \\
\hline 32 & Pseudoniphargus pityusensis & MH592135 \\
\hline 33 & Pseudoniphargus portosancti & MH592136 \\
\hline 34 & Pseudoniphargus ruffoi & MH592137 \\
\hline 35 & Pseudoniphargus salinus & MH592149 \\
\hline 36 & Pseudoniphargus sorbasiensis & LN871175 \\
\hline 37 & Pseudoniphargus sp. 1-Azores & MH592148 \\
\hline 38 & Pseudoniphargus sp. 1-Balearics & MH592138 \\
\hline 39 & Pseudoniphargus sp. 1-Basque & MH592139 \\
\hline 40 & Pseudoniphargus sp. 1-Murcia & MH592140 \\
\hline 41 & Pseudoniphargus sp. 1-Portugal & MH592151 \\
\hline 42 & Pseudoniphargus sp. 2-Andalusia & MH592141 \\
\hline 43 & Pseudoniphargus sp. 2-Canaries & MH592142 \\
\hline 44 & Pseudoniphargus sp. 2-Portugal & MH592143 \\
\hline 45 & Pseudoniphargus sp. 6-Morocco A & MH592144 \\
\hline 46 & Pseudoniphargus sp. 6-Morocco B & MH592145 \\
\hline 47 & Pseudoniphargus stocki & MH592152 \\
\hline 48 & Pseudoniphargus triasi & MH592146 \\
\hline 49 & Pseudoniphargus unisexualis & MH592147 \\
\hline
\end{tabular}


TABLE S2 (continued on next four pages)

List of all the sequences included in the 28S phylogeny, including species names and GenBank accession numbers.

\begin{tabular}{|c|c|c|}
\hline ID & Species & Accessionnumber \\
\hline 1 & Gammarus pulex & MT994447 \\
\hline 2 & Gammarus fossarum & JF965709 \\
\hline 3 & Synurella ambulans & МT994448 \\
\hline 4 & Crangonyx subterraneus & MT994446 \\
\hline 5 & Pseudoniphargus italicus & MT994449 \\
\hline 6 & Pseudoniphargus gorbeanus & KY441101 \\
\hline 7 & Pseudoniphargus portosancti & KY441102 \\
\hline 8 & Pseudoniphargus spiniferus & MT994450 \\
\hline 9 & Pseudoniphargus sp. & KY441100 \\
\hline 10 & Microniphargus leruthi & MT994437 \\
\hline 11 & Microniphargus leruthi & MT994438 \\
\hline 12 & Microniphargus leruthi & МТ994439 \\
\hline 13 & Microniphargus leruthi & MT994440 \\
\hline 14 & Microniphargus leruthi & MT994441 \\
\hline 15 & Microniphargus leruthi & МТ994442 \\
\hline 16 & Microniphargus leruthi & MT994443 \\
\hline 17 & Microniphargus leruthi & MT994444 \\
\hline 18 & Microniphargus leruthi & MT994445 \\
\hline 19 & Microniphargus leruthi & MT994436 \\
\hline 20 & Microniphargus leruthi & KX379004 \\
\hline 21 & Chaetoniphargus lubuskensis & MN914030 \\
\hline 22 & Haploginglymus geos & KY441086 \\
\hline 23 & Haploginglymus morenoi & KY441079 \\
\hline 24 & Niphargellus glenniei & KC315617 \\
\hline 25 & Niphargobates orophobata & KR905879 \\
\hline 26 & Niphargopsis casparyi & EU693291 \\
\hline 27 & Niphargus aberrans & EF617260 \\
\hline 28 & Niphargus aggtelekiensis & MT975472 \\
\hline 29 & Niphargus aitolosi & EU693310 \\
\hline 30 & Niphargus alisadri & KF581049 \\
\hline 31 & Niphargus alpheus & KY617132 \\
\hline 32 & Niphargus altagahizi & KF581059 \\
\hline 33 & Niphargus ambulator & KJ566699 \\
\hline 34 & Niphargus anchialinus & KR905881 \\
\hline 35 & Niphargus andropus & KF218725 \\
\hline 36 & Niphargus antipodes & KY617097 \\
\hline 37 & Niphargus aquilex A1 & KC315604 \\
\hline 38 & Niphargus aquilex A2 & JF420874 \\
\hline 39 & Niphargus aquilex $\mathrm{B}$ & KC315605 \\
\hline 40 & Niphargus aquilex $\mathrm{C}$ & KC315602 \\
\hline 41 & Niphargus aquilex D & KC315603 \\
\hline 42 & Niphargus aquilex E & KC315606 \\
\hline 43 & Niphargus aquilex $\mathrm{F}$ & KC315607 \\
\hline 44 & Niphargus arbiter & KY617099 \\
\hline 45 & Niphargus arethusa & EF617285 \\
\hline 46 & Niphargus auerbachi & EU693292 \\
\hline 47 & Niphargus aulicus & MN914026 \\
\hline 48 & Niphargus bajuvaricus & EF617259 \\
\hline 49 & Niphargus balcanicus & EF617280 \\
\hline 50 & Niphargus bihorensis & KF218726 \\
\hline 51 & Niphargus bilecanus & JQ815550 \\
\hline 52 & Niphargus bisitunicus & KF581050 \\
\hline
\end{tabular}


TABLE S2 (continued)

\begin{tabular}{|c|c|c|}
\hline ID & Species & Accessionnumber \\
\hline 53 & Niphargus borisi & KF581037 \\
\hline 54 & Niphargus boskovici & KR827043 \\
\hline 55 & Niphargus brachytelson & EU693293 \\
\hline 56 & Niphargus brevicuspis & MN914028 \\
\hline 57 & Niphargus brevirostris & MN914008 \\
\hline 58 & Niphargus brixianus & EF617299 \\
\hline 59 & Niphargus bureschi & MN114020 \\
\hline 60 & Niphargus buturovici & MN914022 \\
\hline 61 & Niphargus carniolicus & EF617252 \\
\hline 62 & Niphargus carpathicus & MN114019 \\
\hline 63 & Niphargus cf. gallicus & KF290033 \\
\hline 64 & Niphargus cf. stefanellii & MN914000 \\
\hline 65 & Niphargus cf. stenopus & MN914009 \\
\hline 66 & Niphargus cf. stygius 2 & KX379016 \\
\hline 67 & Niphargus cf. thienemanni & MH172406 \\
\hline 68 & Niphargus chagankae & JQ815441 \\
\hline 69 & Niphargus cornicolanus & MN914003 \\
\hline 70 & Niphargus costozzae & EU693294 \\
\hline 71 & Niphargus croaticus & KT007482 \\
\hline 72 & Niphargus cvajcki & KY617371 \\
\hline 73 & Niphargus dabarensis & JQ815442 \\
\hline 74 & Niphargus dalmatinus & EF617296 \\
\hline 75 & Niphargus dancaui & KF290030 \\
\hline 76 & Niphargus daniali & KF581033 \\
\hline 77 & Niphargus darvishi & KF581041 \\
\hline 78 & Niphargus decui & KF290034 \\
\hline 79 & Niphargus delamarei & EU693295 \\
\hline 80 & Niphargus dimorphopus & EU693296 \\
\hline 81 & Niphargus dimorphus & MN914035 \\
\hline 82 & Niphargus dobati & EF617247 \\
\hline 83 & Niphargus dobrogicus & KF290076 \\
\hline 84 & Niphargus dolenianensis & EF617269 \\
\hline 85 & Niphargus doli & KY617137 \\
\hline 86 & Niphargus dolichopus & EU693297 \\
\hline 87 & Niphargus elegans & EF617297 \\
\hline 88 & Niphargus factor & EU693298 \\
\hline 89 & Niphargus fiseri & MK911610 \\
\hline 90 & Niphargus fjakae & EF617290 \\
\hline 91 & Niphargus fongi & MN914037 \\
\hline 92 & Niphargus fontanus A1 & KC315608 \\
\hline 93 & Niphargus fontanus A2 & EF617304 \\
\hline 94 & Niphargus fontanus $\mathrm{C}$ & KC315609 \\
\hline 95 & Niphargus forelii A & KC315615 \\
\hline 96 & Niphargus forelii B & KC315616 \\
\hline 97 & Niphargus frasassianus & GU973411 \\
\hline 98 & Niphargus frontalis & GU973423 \\
\hline 99 & Niphargus gammariformis & MN114013 \\
\hline 100 & Niphargus gebhardti & KP967556 \\
\hline 101 & Niphargus goricae & KY617447 \\
\hline 102 & Niphargus gottscheeanensis & KY617394 \\
\hline 103 & Niphargus grandii & EU693300 \\
\hline 104 & Niphargus hadzii & EU693301 \\
\hline 105 & Niphargus hebereri & MN913992 \\
\hline 106 & Niphargus hercegovinensis & JQ815549 \\
\hline
\end{tabular}


TABLE S2 (continued)

\begin{tabular}{|c|c|c|}
\hline ID & Species & Accessionnumber \\
\hline 107 & Niphargus hosseiniei & KF581055 \\
\hline 108 & Niphargus hrabei & MN914029 \\
\hline 109 & Niphargus hvarensis & EF617272 \\
\hline 110 & Niphargus ictus & GU973415 \\
\hline 111 & Niphargus ilamensis & KF581039 \\
\hline 112 & Niphargus illidzensis & EU693304 \\
\hline 113 & Niphargus irlandicus & KC315618 \\
\hline 114 & Niphargus iskae & KY617382 \\
\hline 115 & Niphargus jovanovici & MN114014 \\
\hline 116 & Niphargus kapelanus & KY617387 \\
\hline 117 & Niphargus karamani & EU693305 \\
\hline 118 & Niphargus karkabounasi & KP133156 \\
\hline 119 & Niphargus kenki & KY617370 \\
\hline 120 & Niphargus khayyami & JX535353 \\
\hline 121 & Niphargus khwarizmi & KF581056 \\
\hline 122 & Niphargus kochianus A & KC315610 \\
\hline 123 & Niphargus kochianus B & KC315611 \\
\hline 124 & Niphargus kochianus $\mathrm{C}$ & KC315612 \\
\hline 125 & Niphargus kolombatovici & JQ815553 \\
\hline 126 & Niphargus kordunensis & KY617386 \\
\hline 127 & Niphargus koukourasi & EF617277 \\
\hline 128 & Niphargus krameri A & EF617274 \\
\hline 129 & Niphargus krameri B & MN914013 \\
\hline 130 & Niphargus kusceri & JQ815443 \\
\hline 131 & Niphargus labacensis & EF617257 \\
\hline 132 & Niphargus ladmiraulti & GU973463 \\
\hline 133 & Niphargus laisi & EU693309 \\
\hline 134 & Niphargus laticaudatus & KF218717 \\
\hline 135 & Niphargus lessiniensis & EF617300 \\
\hline 136 & Niphargus liburnicus & КT007477 \\
\hline 137 & Niphargus likanus & KY617383 \\
\hline 138 & Niphargus lindbergi & MN114033 \\
\hline 139 & Niphargus longicaudatus & EF617239 \\
\hline 140 & Niphargus longidactylus & EF617266 \\
\hline 141 & Niphargus longiflagellum & MN914004 \\
\hline 142 & Niphargus lourensis & EU693312 \\
\hline 143 & Niphargus luchoffmani & KX379014 \\
\hline 144 & Niphargus lunaris & EU693313 \\
\hline 145 & Niphargus malagorae & KY617384 \\
\hline 146 & Niphargus maximus & EF617279 \\
\hline 147 & Niphargus microcerberus & MN114023 \\
\hline 148 & Niphargus miljeticus & KR905878 \\
\hline 149 & Niphargus minor & MN114028 \\
\hline 150 & Niphargus mirocensis & KR827047 \\
\hline 151 & Niphargus molnari & KP967555 \\
\hline 152 & Niphargus montanarius & GU973419 \\
\hline 153 & Niphargus montellianus & KT878856 \\
\hline 154 & Niphargus moogi & MT975478 \\
\hline 155 & Niphargus multipennatus & KJ566700 \\
\hline 156 & Niphargus mиотаe & KX379024 \\
\hline 157 & Niphargus murimali & KX379026 \\
\hline 158 & Niphargus novomestanus & KY617364 \\
\hline 159 & Niphargus ohridanus & MN114029 \\
\hline 160 & Niphargus orcinus & EU693315 \\
\hline
\end{tabular}


TABLE S2 (continued)

\begin{tabular}{|c|c|c|}
\hline ID & Species & Accessionnumber \\
\hline 161 & Niphargus pachypus & KC733825 \\
\hline 162 & Niphargus pachytelson & EU693316 \\
\hline 163 & Niphargus parenzani & MN913997 \\
\hline 164 & Niphargus pasquinii & EF617244 \\
\hline 165 & Niphargus patrizii & MN914011 \\
\hline 166 & Niphargus pectencoronatae & MN914010 \\
\hline 167 & Niphargus pectinicauda & EF617258 \\
\hline 168 & Niphargus persicus & KF581036 \\
\hline 169 & Niphargus pincinovae & KY617139 \\
\hline 170 & Niphargus plateaui & GU973468 \\
\hline 171 & Niphargus podgoricensis & KR905875 \\
\hline 172 & Niphargus podpecanus & KY617374 \\
\hline 173 & Niphargus poianoi & KX379006 \\
\hline 174 & Niphargus polymorphus & EF617282 \\
\hline 175 & Niphargus pontoruffoi & KF290027 \\
\hline 176 & Niphargus pretneri & EF617294 \\
\hline 177 & Niphargus pupetta & EU693318 \\
\hline 178 & Niphargus puteanus & EF617302 \\
\hline 179 & Niphargus racovitzai & KF290065 \\
\hline 180 & Niphargus rejici & EF617283 \\
\hline 181 & Niphargus rhenorhodanensis $\mathrm{ABC}$ & EF025814 \\
\hline 182 & Niphargus rhenorhodanensis DE & EF025801 \\
\hline 183 & Niphargus rhenorhodanensis DE & EF025831 \\
\hline 184 & Niphargus rhenorhodanensis FG & KX379033 \\
\hline 185 & Niphargus rhenorhodanensis $\mathrm{H}$ & KX379013 \\
\hline 186 & Niphargus rhenorhodanensis I & EF025841 \\
\hline 187 & Niphargus rhenorhodanensis JK & EF025810 \\
\hline 188 & Niphargus romuleus & MT975475 \\
\hline 189 & Niphargus salernianus & MN914014 \\
\hline 190 & Niphargus salonitanus & KY617147 \\
\hline 191 & Niphargus salzburgensis & KJ566697 \\
\hline 192 & Niphargus sanctinaumi & EU693320 \\
\hline 193 & Niphargus schellenbergi 1 & EF617267 \\
\hline 194 & Niphargus schellenbergi 2 & KC315620 \\
\hline 195 & Niphargus scopicauda & EF617261 \\
\hline 196 & Niphargus sharifi & KF581048 \\
\hline 197 & Niphargus slovenicus & EU693322 \\
\hline 198 & Niphargus sohrevardensis & KF581034 \\
\hline 199 & Niphargus sp. Arkadi & MN114032 \\
\hline 200 & Niphargus sp. BIH1 & EF617268 \\
\hline 201 & Niphargus sp. HudaLuknja & EF617246 \\
\hline 202 & Niphargus sp. Iran 9 & KF581040 \\
\hline 203 & Niphargus sp. Iskavas & EF617291 \\
\hline 204 & Niphargus sp. Italy A & KJ566701 \\
\hline 205 & Niphargus sp. Jelovica & MN114022 \\
\hline 206 & Niphargus sp. MN914012 & MN914012 \\
\hline 207 & Niphargus sp. MN914023 & MN914023 \\
\hline 208 & Niphargus sp. Meskla & MN114031 \\
\hline 209 & Niphargus sp. Montenegro & EF617278 \\
\hline 210 & Niphargus sp. Neraidosplilios & MN114030 \\
\hline 211 & Niphargus sp. Podutik & EF617251 \\
\hline 212 & Niphargus sp. Prepadna & EF617249 \\
\hline 213 & Niphargus sp. Ro1 & KF218728 \\
\hline 214 & Niphargus sp. Ro2 & KF218724 \\
\hline
\end{tabular}


TABLE S2 (continued)

\begin{tabular}{cll}
\hline ID & Species & Accessionnumber \\
\hline 215 & Niphargus sp. Ro4 & KF218732 \\
216 & Niphargus sp. Ro5 & KJ566693 \\
217 & Niphargus sp. Spain1 & KY441088 \\
218 & Niphargus sp. Spain2 & KY441083 \\
219 & Niphargus sp. Spain3 & KY441081 \\
220 & Niphargus speziae & MT975471 \\
221 & Niphargus sphagnicolus & EF617270 \\
222 & Niphargus spinulifemur B & EU693323 \\
223 & Niphargus spoeckeri & EU693324 \\
224 & Niphargus stefanellii & MN913999 \\
225 & Niphargus stenopus & EF617284 \\
226 & Niphargus steueri & KT007489 \\
227 & Niphargus stochi & JQ815551 \\
228 & Niphargus strouhali alpinus & EF617254 \\
229 & Niphargus stygius & MT975470 \\
230 & Niphargus styx & KX379023 \\
231 & Niphargus subtypicus & EU693326 \\
232 & Niphargus lurensis & MT975504 \\
233 & Niphargus tatrensis reyesdorfensis & MT975494 \\
234 & Niphargus salzburgensis & MT975492 \\
235 & Niphargus tatrensis schneebergensis & MT975495 \\
236 & Niphargus tatrensis tatrensis & MT975496 \\
237 & Niphargus tauri & EF617245 \\
238 & Niphargus tauricus & KF719274 \\
239 & Niphargus thienemanni & EF617301 \\
240 & Niphargus thuringius & KJ566695 \\
241 & Niphargus timavi & MN914034 \\
242 & Niphargus tonywhitteni & KX379045 \\
243 & Niphargus transsylvanicus & KF218716 \\
244 & Niphargus tridentinus & KT878857 \\
245 & Niphargus trullipes & EF617281 \\
246 & Niphargus urmiensis & MK911608 \\
247 & Niphargus vadimi & KF719275 \\
248 & Niphargus vinodolensis & EF617298 \\
249 & Niphargus virei A & DQ119309 \\
250 & Niphargus virei B & KX379035 \\
251 & Niphargus virei C & EF617237 \\
252 & Niphargus vjetrenicensis & EU693329 \\
253 & Niphargus wolf A & EF617250 \\
254 & Niphargus zagorae & KR827044 \\
255 & Niphargus zagrebensis & EF617295 \\
\hline & & \\
& & \\
& & \\
& &
\end{tabular}

